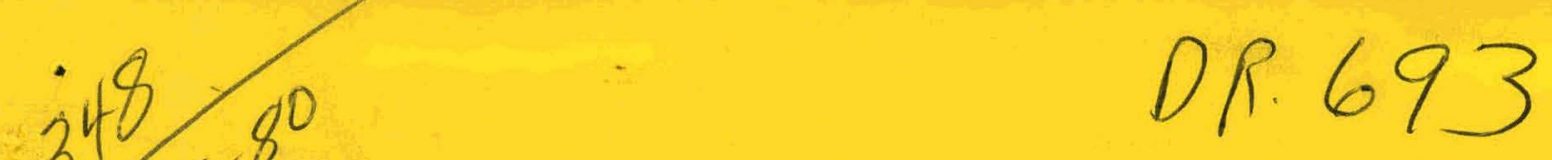

DOE/NASA CONTRACTOR

DOE/NASA CR-161340 REPORT

\title{
PROTOTYPE SOLAR HEATING AND COMBINED HEATING AND COOLING SYSTEMS (Quarterly Report No. 9)
}

Prepared from documents furnished by

General Electric Company

Space Division

Post Office Box 8661

Philadelphia, Pennsylvania 19101

Under Contract NAS8-32092 with

National Aeronautics and Space Administration

George C. Marshall Space Flight Center, Alabama 35812

For the U. S. Department of Energy

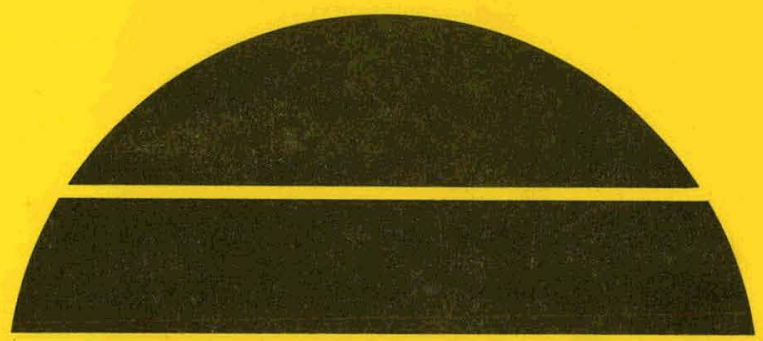




\section{DISCLAIMER}

This report was prepared as an account of work sponsored by an agency of the United States Government. Neither the United States Government nor any agency Thereof, nor any of their employees, makes any warranty, express or implied, or assumes any legal liability or responsibility for the accuracy, completeness, or usefulness of any information, apparatus, product, or process disclosed, or represents that its use would not infringe privately owned rights. Reference herein to any specific commercial product, process, or service by trade name, trademark, manufacturer, or otherwise does not necessarily constitute or imply its endorsement, recommendation, or favoring by the United States Government or any agency thereof. The views and opinions of authors expressed herein do not necessarily state or reflect those of the United States Government or any agency thereof. 


\section{DISCLAIMER}

Portions of this document may be illegible in electronic image products. Images are produced from the best available original document. 
This report was prepared to document work sponsored by the United States Government. Nelther the United States nor 1 ts agents the United States Department of Energy, the United States National Aeronautics and Space Administration, nor any federal employees, nor any of their contractors, subcontractors or thelr employees, make any warranty, express or implied, or assume any legal liability or responsibility for the accuracy, completeness, or usefulness of any information, apparatus, product or process disclosed, or represent that 1ts use would not infringe privately owned rights. 
TECHNICAL REPORT ST ANDARD TITLE PAGE

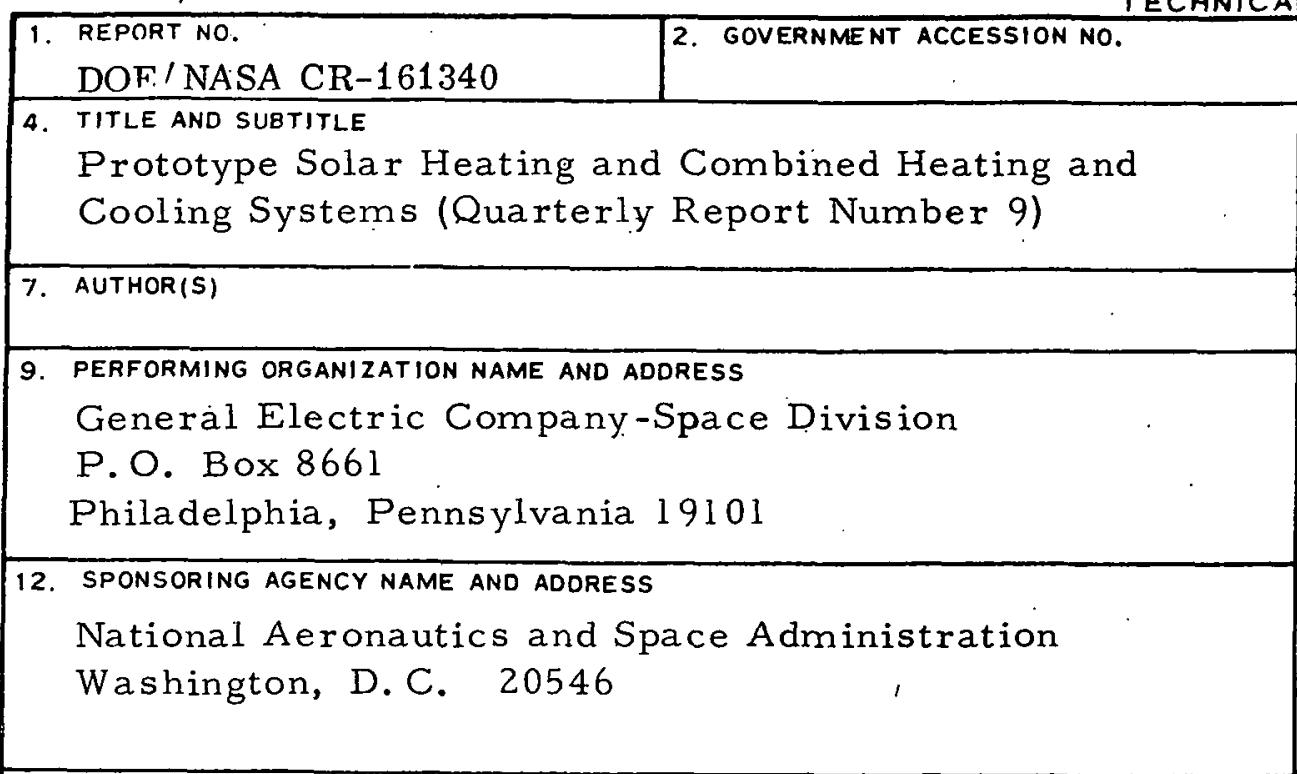

\begin{tabular}{|l|} 
3. RECIPIENT'S CATALOG NO. \\
5. $\begin{array}{c}\text { REPORT OATE } \\
\text { OCtObE } 2,1978\end{array}$ \\
\hline 6. PERRORMING ORGANIZATION CGIDE \\
8. PERFORMING ORGANIZATION REPORT \# \\
10. WORK UNIT NO. \\
$\begin{array}{c}\text { 11. CONTRACT OR GRANT NO. } \\
\text { NAS } 8-32092\end{array}$ \\
\hline
\end{tabular}

13. TYPE OF REPOR'; \& PERIOD COVERED

Contractor Report July' 78 - Sept. ${ }^{\prime} 78$

14. SPONSORING AGENCY CODE

15. SUPPLEMENTARY NOTES

This work was accomplished under the technical management of

Mr. William L. Moore, George C. Marshall Space Flight Center, Ala.

16. ABSTRACT

The General Electric Company is developing eight prototype solar heating and combined heating and cooling systems. This effort includes development, manufacture, test, installation, maintenance, problem resolution, and performance evaluation.

All cost and proprietary data. ha've been removed from this report.

\begin{tabular}{|c|c|c|c|}
\hline 17. KEY WOROS & $\begin{array}{l}\text { 18. DISTRIBUTI } \\
\text { WILLIAM } \\
\text { Manager, }\end{array}$ & $\begin{array}{l}\text { UEMENT } \\
\text { UC } \\
\text { ROKSBANK, } \\
\text { Energy Appl } \\
\text { ects }\end{array}$ & Lations \\
\hline $\begin{array}{c}\text { 19. SECURITY CLASSIF. (of this roport) } \\
\text { Unclassified }\end{array}$ & $\begin{array}{l}\text { 20. SECURITY CLASSIF. (of thl moo) } \\
\text { Unclassified }\end{array}$ & $\begin{array}{c}21 . \text { NO. OF PAGES } \\
43\end{array}$ & $\begin{array}{l}\text { 22. PRICE } \\
\text { NTIS }\end{array}$ \\
\hline
\end{tabular}


THIS PAGE

\section{WAS INTENTIONALLY LEFT BLANK}


TABLE OF CONTENTS

$\underline{\text { Section }}$

Page

INTRODUCTION................... v

PART I $\quad$ SUMMARY ......................

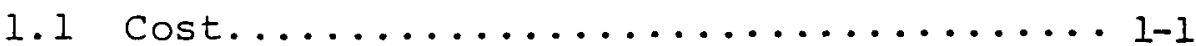

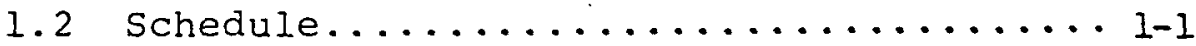

1.3 Technical Performance............... 1-4

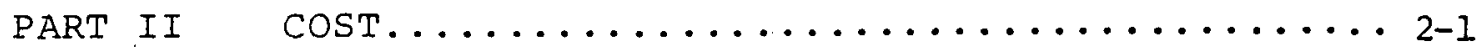

PART III SCHEDULES .................... 3-1

PART IV TECHNICAI PERFORMANCE............... 4-I

Task 1.1 Program Management........... 4-1

1.1 Program Direction (WBS 1.1.1) ........ 4-1

1.2 Program Planning and Control (WBS 1.1.2) 4-1

1.2.1. Program.................. 4-1

1.2 .2 Data Management............. 4-3

1.2.3 Change Control................. 4-3

1.3 Quality Assurance (WBS 1.1.3) ........4 4-3

1.3.1 Significant Quality
Assurance Activities........ 4-3

Task 1.2 System Development...........4-6

2.1 Introduction................... 4-6

2.2 System Integration............... 4-6

2.3 System Development (WBS 1.2 .2 ) ...... 4-6

2.3 .1 Heating systems (WBS 1.2.2.1) ... 4-6

2.3.2 Heating and Cooling Systems

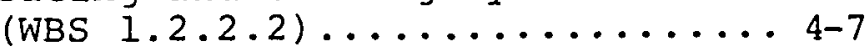

2.4 Test (WBS 1.2 .3$) \ldots \ldots \ldots \ldots \ldots \ldots \ldots \ldots \ldots$

Task 1.3 Deliverable Hardware........... 4-22

3.1 Normal...................... 4-22

3.2 spokane....................... 4-22

3.3 Milwaukee..................... 4-22

3.4 Ft. Meade.................... 4-22

Task 1.4 Operational Test Sites..........4-23

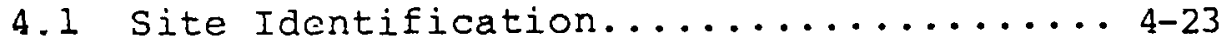

4,2 . Site Installations............... 4-23 
TABLE OF CONTENTS

(Continued)

4.2 .1 HSF-2 Normal................. 4-23

4.2.2 HГПM-2. Spnkane............... 4-26

4.2 .3 HSF-1 Ft. Meade, Md........... 4-27

4.2.4 HCOM-1 Milwaukee, Wisc.......... 4-27

4.2 .5 HCSF-1 Dallas, Texas............ 4-27

4.2 .6 HCSF-2 Shenendoah, Ga.......... 4-27

4.2.7 HCСOM 1 and 2 - Muscle shoals,

Ala. and Murphy, N. C......... 4-27 


\section{INTRODUCTION}

The Quarterly Status Report (Data Requirements Item No. 500-10) provides a summary of the cost, schedule and technical progress of the program. Since it includes and extends the information included in the Monthly Status Reports (Data Requirements Item No. 500-11) it also meets the contract requirement of a monthly status report. It is supplemented by the financial status report (Data Requirements Item No. 500-27) submitted under separate cover.

The report format is:

$$
\begin{aligned}
& \text { Part I - Summary } \\
& \text { Part II - Cost } \\
& \text { Part III - Schedules } \\
& \text { Part IV - Technical Performance }
\end{aligned}
$$

The report is integrated with the program management systems being used on the program, so, where possible, multiple use of program data such as schedules or financial status reports has been accomplished. 
PART 1

SUMMARY

\subsection{Costs}

This section has been deleted

\subsection{Schedule}

The working program schedule is posted on the walls of the Program Control Room and is used to monitor program status at daily "standup" meetings. Reviews with GE management are held in the control Room to take advantage of the detail schedule data base. A summary schedule is shown in Figure $1-1$.

The GE/NASA meetings held this period were the Quarterly Review, and a 3-ton Prototype Design Review on August 10 and 11. The Installation Acceptance Reviews were held on July 20 for spokane, Washington and september 7 for Normal, Illinois, for the ' purpose of officially releasing the heating systems to NASA/MSFC. 


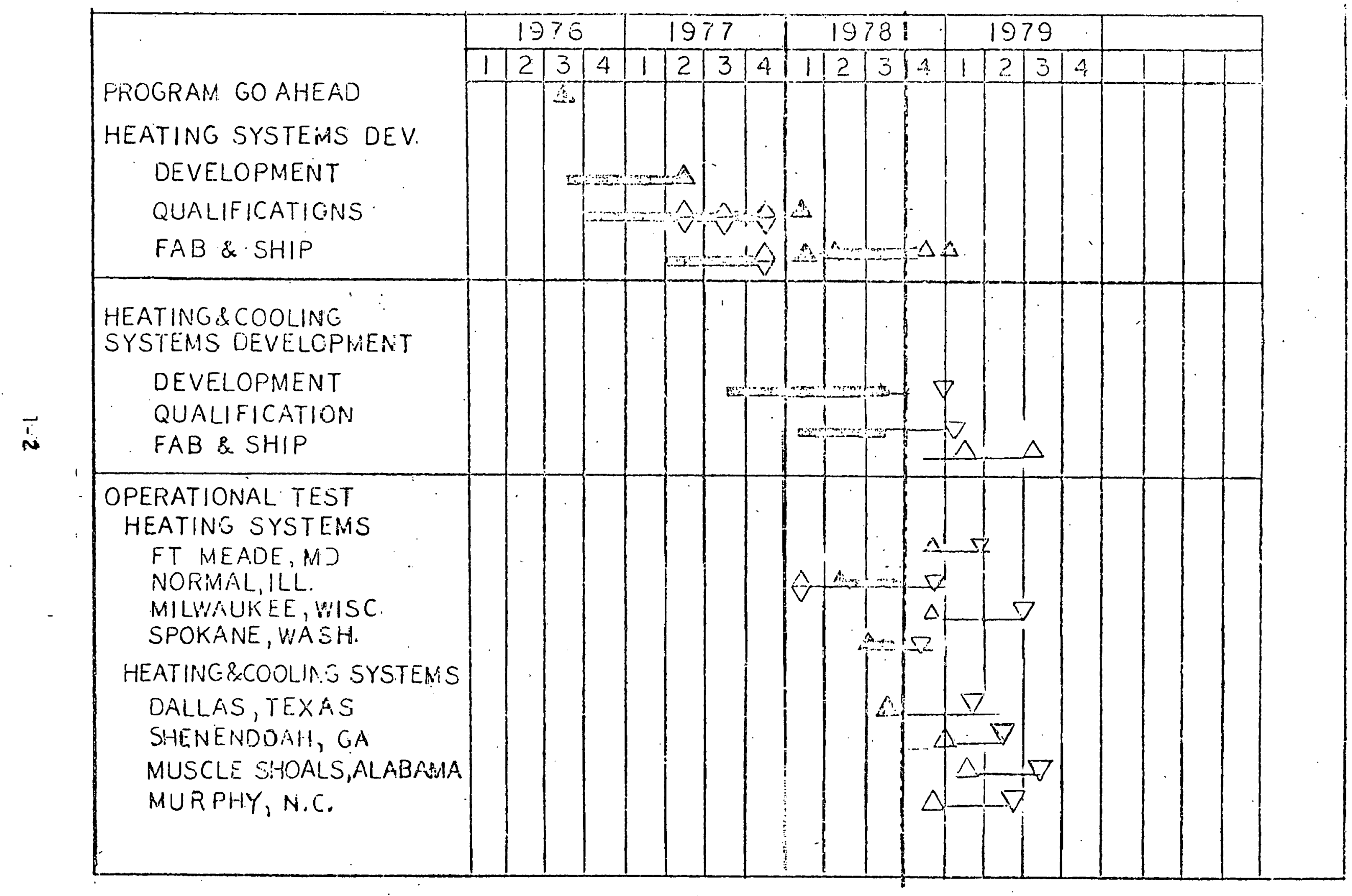

Figure 1-1. Master Program Flan 
A GE/NASA working meeting was held in Huntsville to discuss cost growth options on July 19, 1978. On July 25, another meeting relative to cost was held in Washington with DOE, NASA and GE. As a result of the meeting in Washington, a hold was placed on the second 3-ton and the 10-ton units. Decision on final option is still pending. 


\subsection{IECHNICAL PERFORMANCE}

\section{3 .1 - PROGRAM MANAGEMENT}

Program direction continued per plan.

\section{3 .2 - DEVELOPMENT}

There was no significant activity in the analysis and integration sub-task.

TC-10l collectors, including coilzak and Alglas reflectors, completed the performance test at Valley Forge.

Due to funding limitations, essentially all'design and procure, ment activity was discontinued for the REH-100. Engineering and fabrication effort has been restricted to one REH-30. Low level drafting effort continues during this quarter with emphasis on the completion of the REH-30 top level assembly drawings. Fabrication and testing of several key components for the REH-30 was completed.

The two-staqe multi-vane expander for the REH-30 was tested for the first time this period. Test results were generally good with the exception of expander efficiency, which is discussed in more detail on Part IV. Development testing of the feed pump was also, underway this quarter.

\section{3 .3 - DELIVERABLES}

An initial shipment of hardware collectors EMM and associated hardware was delivered to Ft. Meade. Shipment of hardware to Milwaukee site will commence in the next quarter.

\section{3 .4 - OPERATIONAL TEST}

Two additional sites for potential use were identified this 
quarter. The first is a single-family residence in Shenandoah, Georgia and the second a TVA building in Murphy, North Carolina.

System design has been completed for the Milwaukee site and the final Design Review was held late september. 
PART II

cost

This section has been deleted 
PART III

SCHEDULES

Summary program schedules are shown in Figures 3-1, 3-2, and 3-3. These schedule data are extracted from the detailed program working schedules posted in the Control Room at Valley Forge.

Figure 3-1 is the summary key events schedule. A GE/NASA working meeting was held in Huntsville to discuss cost growth options on July 19, 1978. On July 25, another meeting relative to cost was held in Washington with DOE, NASA and GE. Decision on final option is still pending. Other key meetings for the period included a Prototype Design Review, a Quarterly Review on August 10 and 11 and the IAR for Normal, I11. on September 6. The Design Review concentrated on the 3-ton system only.

Due to funding limitations, essentially all design and procurement activity was discontinued for the REH-100 this period. Engineering and fabrication effort has been restricted to one REH-30. Low level drafting effort continues during this quarter with emphasis on the completion of the REH-30 top level assembly drawings.

Fabrication and testing of several key components for the REH-30 was completed. rigure $3-2$ is the schedule for the WBS elcments.

Figure 3-3 shows the data deliveries. During this period, all scheduled software deliveries were completed. 


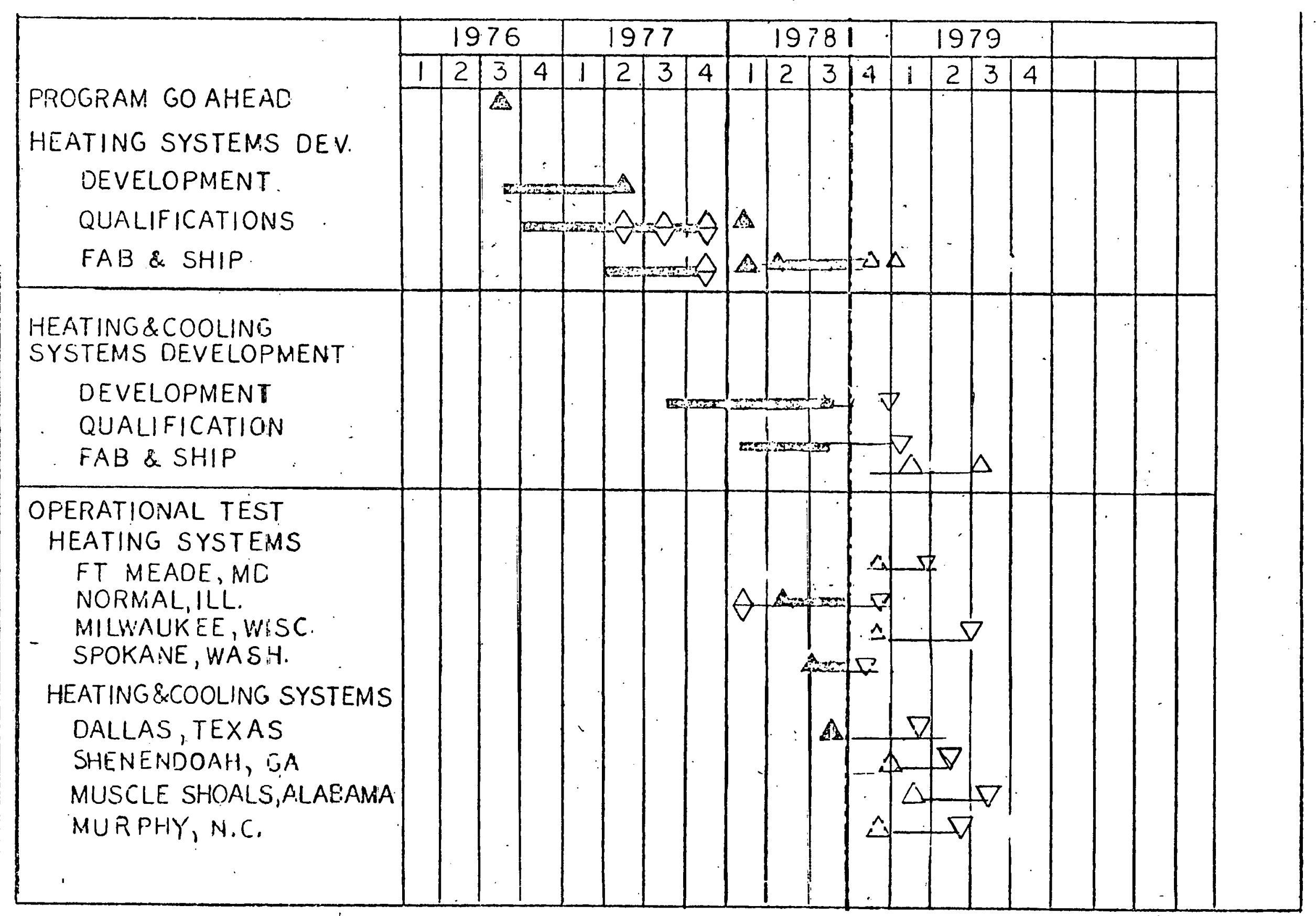

Figure 3-1. Master Program Plan 


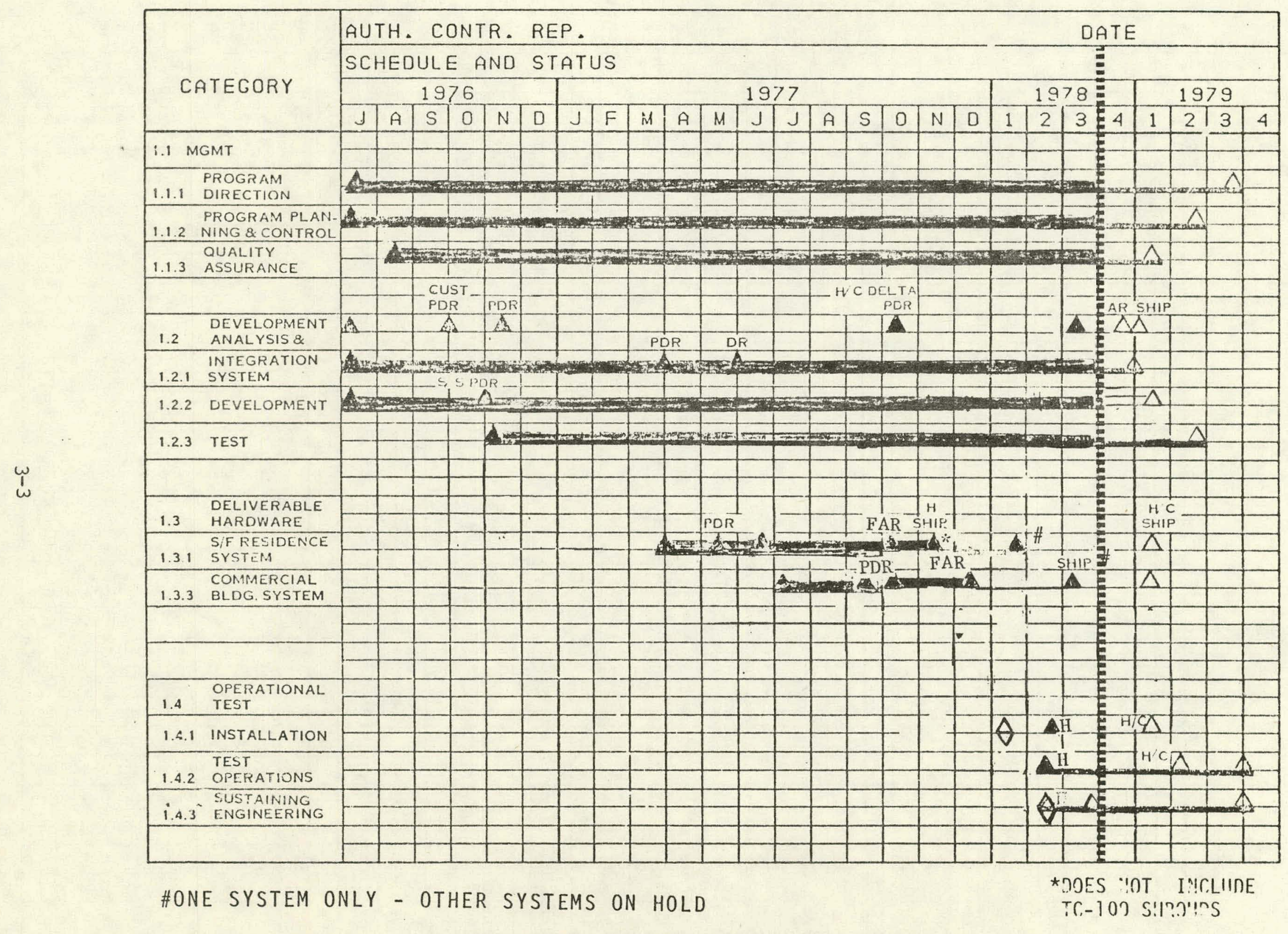

Figure 3-2. WBS Element Schedule and Status 
4. SYSTEM PEAF ORMANCE SPLCIFICATIOH

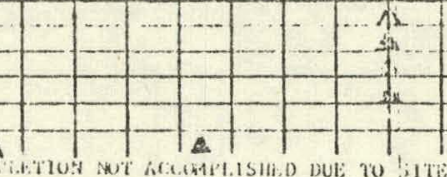

S. CHANGE PROPOSAL ANO ASSOCIATEO PLAN

1. PRELIMINARY OESIGN REVIEW UATA

Q. PROTOTYPE DESIGM REVIEW DATA

9. FiRst Aaticie peview data

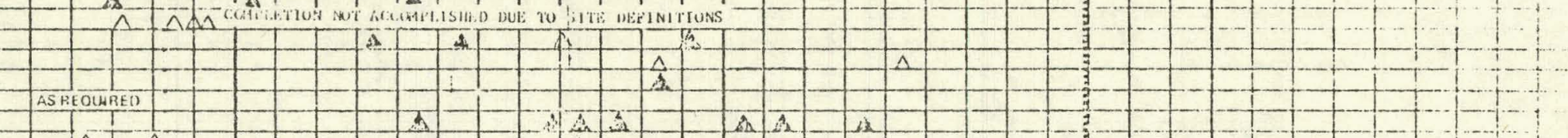

10. QUARTERL $Y$ REPORT

11. HONHIMLV STATUS HLPUH

12. ACCE PTANGE DATA PACKAGE

13. QUALIFICAIION \& ACCEPTANCE IEST PHOCEOURES

14. QURLIFICATIOH TEST AND/OR ANALYSI GIEPORT

15. SiLCISLL HANDLING WSTAL 'AHO MAIN? TOOL UST 16. SPARE PARTS LIST

11. INSTALL, OPERATIONAL MAINT MANGALS

18. WAZARO AMALYSis $\triangle$.

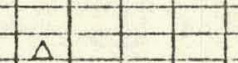

23. SYSTEN PE RF ORMANCE REPORT

24. SAFETY AMO HEALTH PLAN

25. WE W TECHNOLOGY REPORTINO PLAN

25. WORK BREAKDOWN STRUCTURE ANO DICTIONARY

27. FIMANCIAL MANAGELAENT REPOAT

28. MSTTALLATION ACCEPTANCE REVIEW

AS FENUIMED

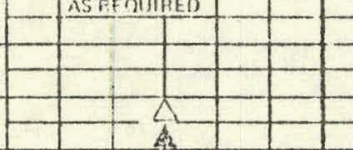

(C) * LATE DELIVERY

$+$
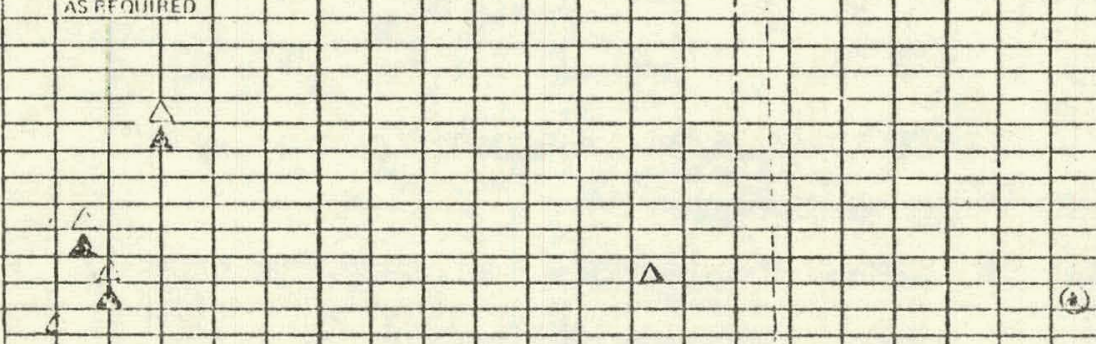

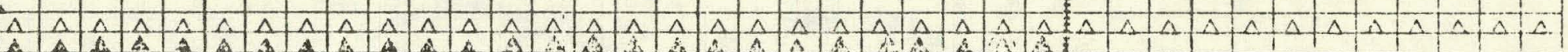

Figure 3-3. Data Reqiurements Status 
PART IV

TECHNICAL PERFORMANCE 
SECTION I

TASK 1.1 - MANAGEMENT

\subsection{Program Direction (WBS 1.1 .1 )}

During this period program operation continued in the manner established during. the initial quarters. The program team shown in Figure $4-1$ is the same as shown in the last quarter.

The GE/NASA meetings held this period were. the Quarterly Review; and a 3-ton Prototype Design Review on August 10 and 11 .

On September 7, 1978, the Installation Acceptance Review was held at Normal, I11. to release the heating system to NASA/MSFC. A set of action items remains to be completed.

A GE/NASA working meeting was held in Huntsville to discuss cost growth options on July 19, 1978. On July 25, another meeting relative to cost was held in Washington with DOE, NASA and GE. As a result of the meeting in Washington, a hold was placed on the second 3-ton and the 10-ton units. Decision on finat option is still pending.

\subsection{Program Planning and Control (WBS 1.1.2)}

\subsubsection{Program Control}

The basic program control tool being used on this program is the control room. It was used during this period to schedule key milestones and program activities and monitor their status. This control room represents the official program schedule against which GE's technical status and progress is monitored. The scheduled data required for the monthly, quarterly and management reports is extracted from the control room posting. The schedules in the control room include the overall program 


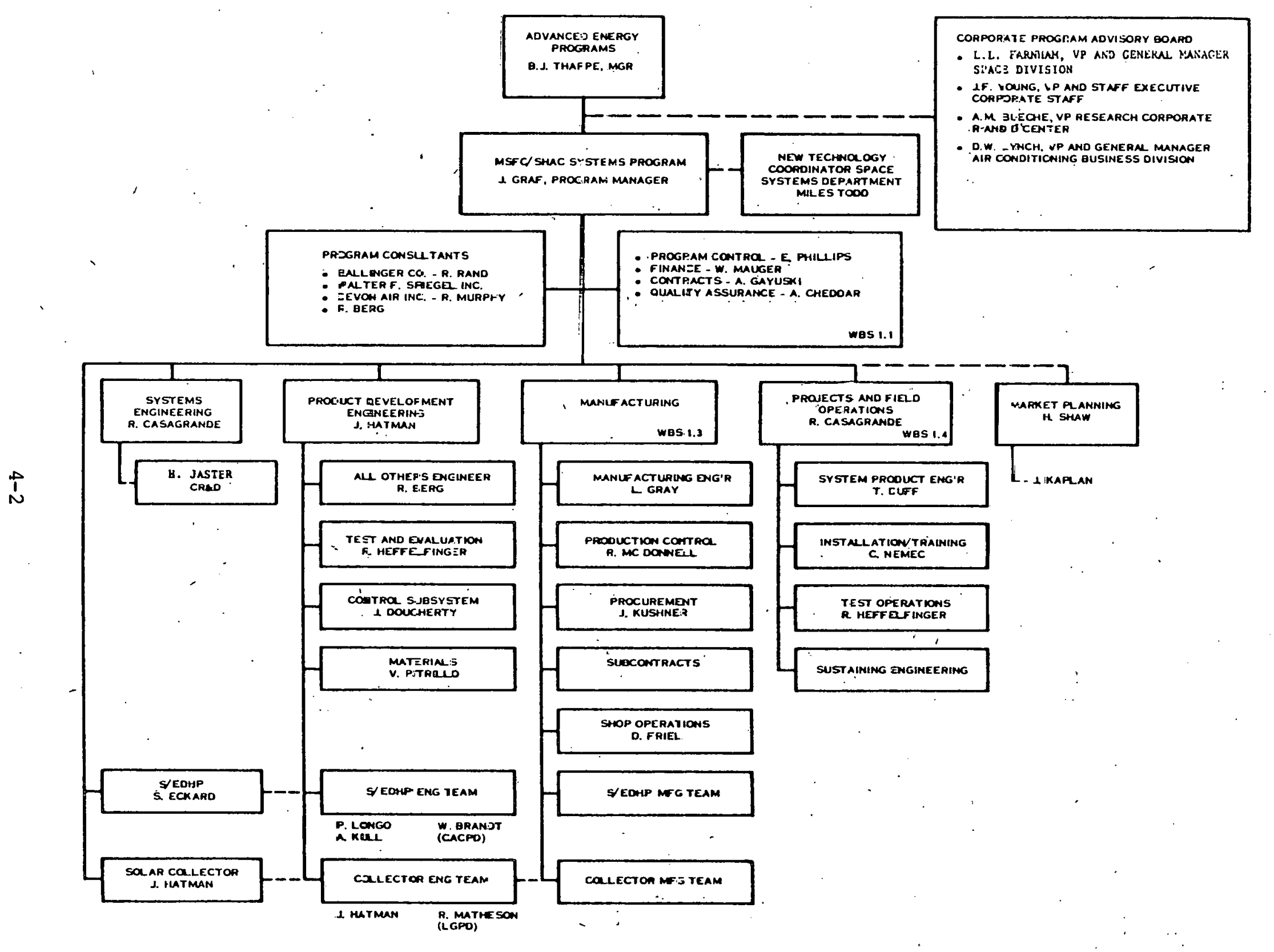

Figure 4-1. Program Organization 
summary with detailed task schedules on the side walls. The individual task sections of the control room schedules are monitored and maintained by the responsible task leaders. Program status meetings are held frequently ( 3 to 5 times per week) to follow hardware items. Problems involving interactions are identified and resolved at these meetings by the assignment of action items which are posted and monitored in the control room.

In the budgets area, the program was monitored on the basis of the revised profile presented in this quarterly report. Overall budget results are analyzed weekly and are available on a continuing basis for inspection by management.

\subsubsection{Data Management}

The scheduled data submittals completed during this period were as follows:

Data Requirement No.

$\begin{array}{ll}-10 & \text { Quarterly Report No. } 8 \\ -11 & \text { Monthly Status Report (2) } \\ -17 & \text { IOM Manuals } \\ -26 & \text { Financial Management Report - } \\ & \text { Monthly (2) } \\ -27 & \text { Quarterly Financial Report }\end{array}$

\subsubsection{Change Control}

The status of Change Proposals is given in Table 4-1.

The status of the Control Modifications is given in Table 4-2.

\subsection{Quality Assurance}

\subsubsection{Significant Qualily Assurance Activities}

None this period. 
This page has been deleted.

4-4 
This page has been deleted.

4-5 
SECTION 2

TASK 1.2 - SYSTEM DEVELOPMENT

\subsection{INTRODUCTION}

2.2 System Integration

No significant activity this period.

\subsection{System Development}

\subsubsection{Heating Systems (WBS 1.2.2.1)}

\subsubsection{Collectors (WBS 1.2.2.1.1) (TC-100)}

2.3.1.1.1. Collector Design and Performance Verification

No significant activity this period.

\subsection{Collector Integration}

No significant activity this period.

\subsection{Collector Primary Loop}

The special oxidation tests on copper serpentine segments have been temporarily suspended due to equipment (furnace, etc) availability. A second cyclic test facility is nearing completion.

A commerically available diverting valve (V4) has been identified and shall'be used as applicable.

2.3.1.1.4 through 2.3.1.6 Ancillary Components for Heating Systems

No significant activity this period. 
Page 4-7 and 4-8 have been deleted as they contained General Electric Proprietary Information 
THIS PAGE

WAS INTENTIONALLY

LEFT BLANK 
fluid inlet temperature. TC-100 test data is also shown for proof of interchangeability between the 10 shroud and 8 shroud modules. The Alglas reflector units show a performance advantage. A switch-over to Alglas will occur when the present Coilzak stock is depleted.

\subsubsection{2 through 2.3.2.6 Ancillary Components for the Heating and Cooling System} Component specifications were updated and modified to satisfy the TC-101 requirements for heating and cooling systems.

\subsubsection{Cooling Controls Subsystem}

No significant activity in this time period. Changes to the current system design will only occur if indicated in the 3-ton or 10-ton Rankine heat pump component test.

\subsubsection{Electrical Subsystem}

No significant activity in this time period.

\subsubsection{System Integration}

No significant activity in this time period.

\subsubsection{Cooling Subsystem}

Due to funding limitations, essentially all design and procurement activity was discontinued for the REH-100. Engineering and fabrication effort has been restricted to one REH-30. Low level drafting effort continues during this quarter with emphas is on the completion of the REH-30 top level assembly drawings.

Fabrication and testing of several key components for the REH-30 was completed. Test results are discussed below.

\subsection{Expander, Two-Stage REH-30}

The two-stage multi-vane expander for the REH-30 was first tested on September 21 with 
FC-88/Krytox $143 A D$ oil as the working fluid. Test results were generally good with the exception of expander efficiency. Ouring a seven hour testing period, expander speed covered the range of 0 to $2200 \mathrm{rpm}$. Maximum vapor temperature and pressure into the expander was $285^{\circ} \mathrm{F}$ and 210 psia respectively; at design vapor flowrate of $1094 \mathrm{lb} / \mathrm{hr}$. While the inlet temperature was $5^{\circ} \mathrm{F}$ below design point, pressure was 10 psi above design point. Output power was below design point since internal expander clearances and expander luhrication techniques were not optimized. Vane pressure balancing, noise level, and low speed torque characteristics were satisfactory. .

Inspection of the expander after disassembly indicated slight vane damage due to foreign debris, and slight interference rubbing of the first stage rotor. Evidence of insufficient first stage lubrication was indicated. Expander and test facility modificaions are being made for the resumption of testing. Figure 4-3 shows the major components of the REH-30 two-stage expander.

\subsection{Expander/Compressor Coupling}

The over-running clutches, magnetic drives and Inconel 718 drive partitions for the REH-30 and REH-100 have been received. Testing of the RE'i-30 magnetic drive at room temperature and at $190^{\circ} \mathrm{F}$ has been completed. Static testing and dynamic testing up to $2200 \mathrm{rpm}$ has been completed for the REH-30 magnetic drive. Test results show a magnetic drive efficiency of $99 \%$ and a $22 \%$ safety factor on torque capacity at design point conditions. Testing of the REH-100 magnetic drive is planned for next quarter. Figure 4-4 shows the key components of the REH-30 magnetic drive, and Figure 4-5 shows the magnetic drive on tes $\bar{t}$.

\subsection{REH-30 Feed Pump}

Development testing of the pump has been underway for most of this quarter. Except 


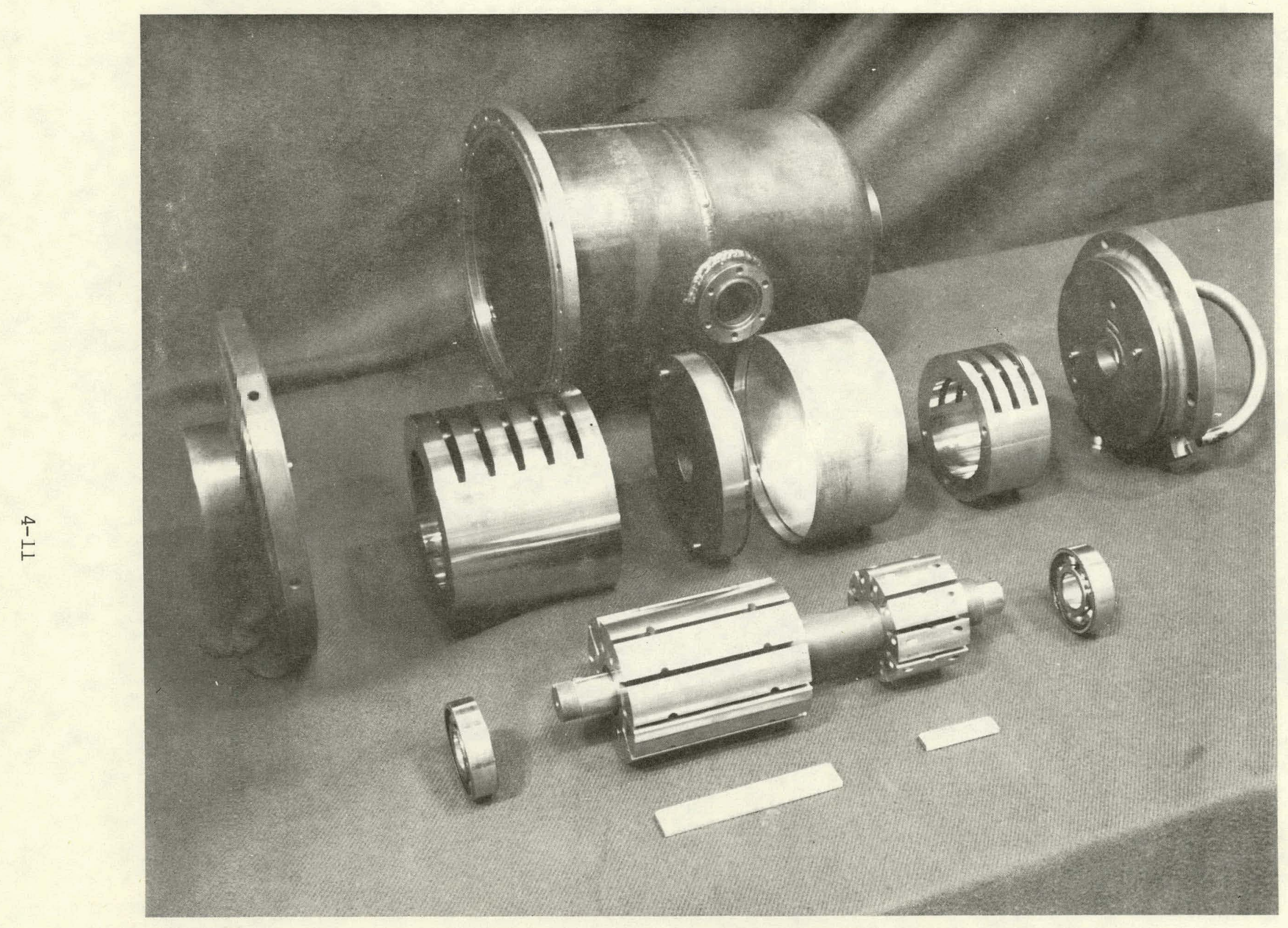

FIGURE 4-3. REH-30 TWO-STAGE EXPANDER 


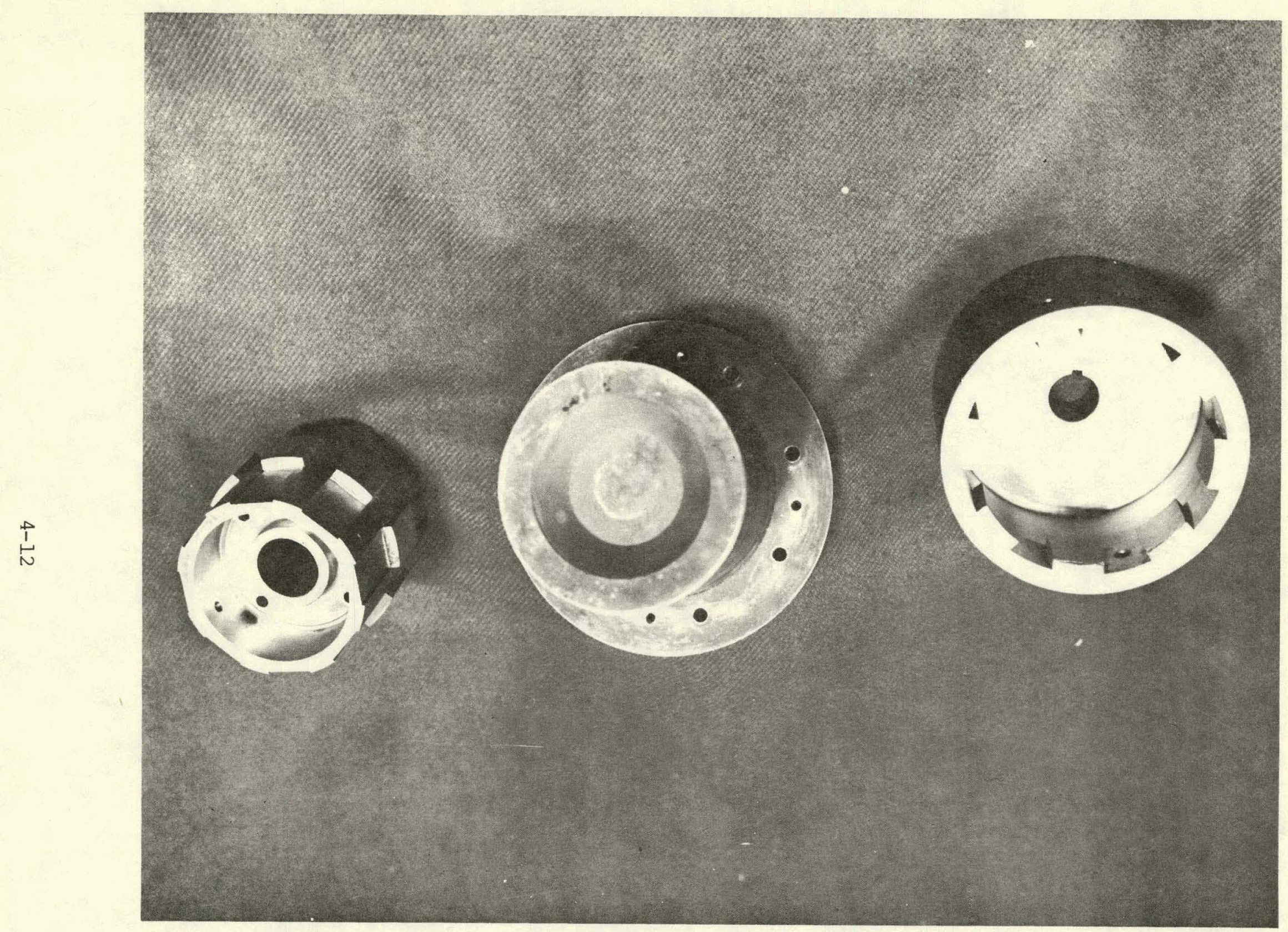

FIGURE 4-4. REH-30 MAGNETIC DRIVE 


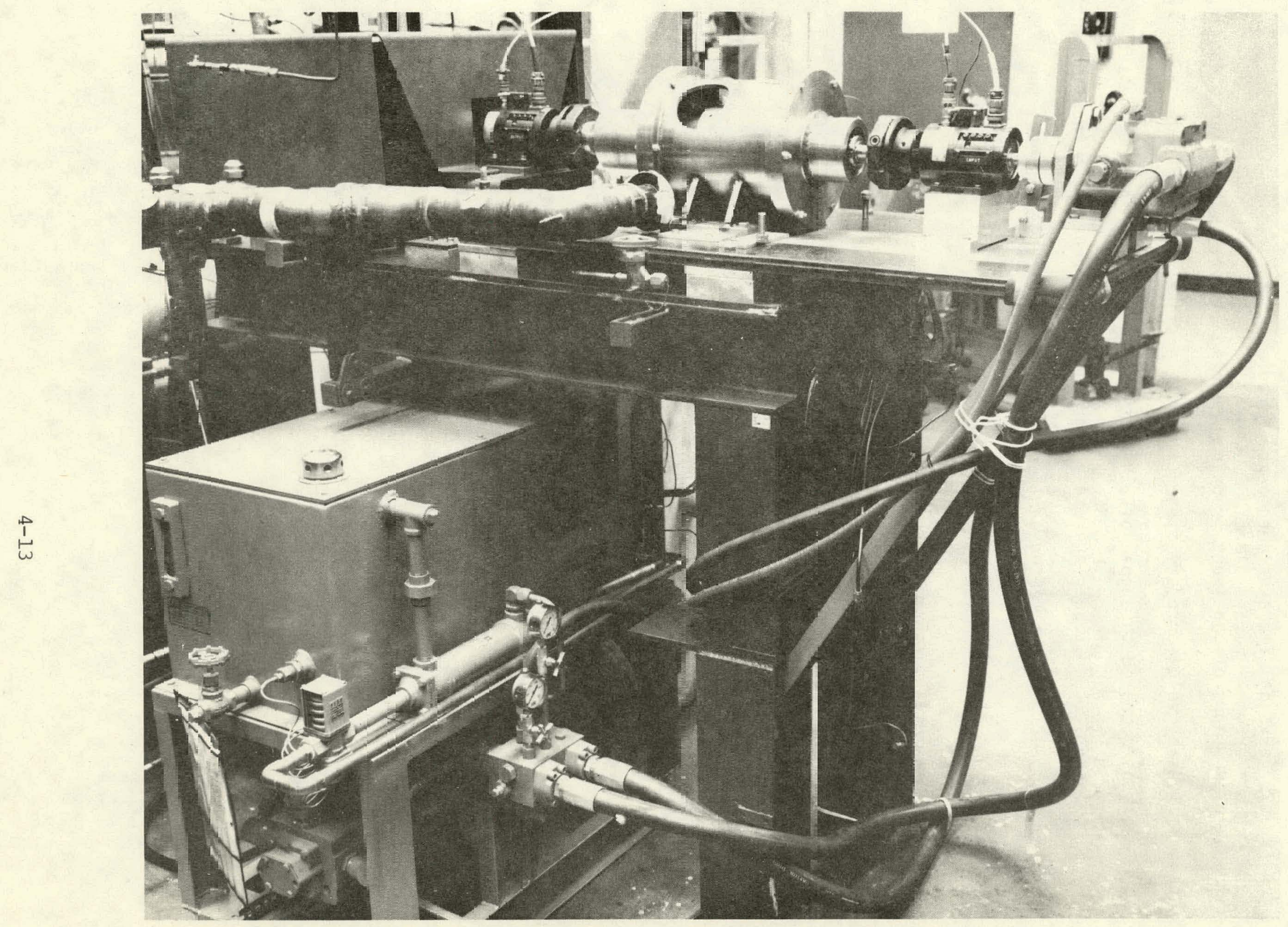

FIGUR 4-5. REH-30 MAINETIC DRIVE ON TEST 
for power consumption, performance of the pump has been satisfactory. As of F.W-39, 800 hours of time have been accumulated with the last build-up accounting for over 600 hours of continuous running. During this brief endurance, there has been no loss of volumetric efficiency. At the present time, the power input is 400 watts as compared to a goal of 254 watts at design flowrate and pressure rise. Pump components (thurst bearing) are being modified to reduce the input power level. These components will be tested early next quarter. Figure 4-6 shows the REH-30 pump on test.

\subsection{Heat Exchangers}

Fabrication of two KEH-3U regenerators has been completed and fabrication of two REH- 100 regenerators are $90 \%$ complete. Two REH-30 and two REH-100 "Heliflow" vapor generators have been received. Thermal insulation is to be applied to all four heat exchangers. The REH-30 expander test facility contains a "Heliflow" (Graham Mfg. Co.) vapor generator. During the seven hour expander testing discussed above, this vapor generator performed satisfactorily.

The REH-30 plate-fin outdoor condenser coil was received and installed in the REH-30 outdoor unit. This coil and fan system was air flow tested at Lau Industries. Test results indicated a $25 \%$ lower fan power than was predicted at design point conditions.

\subsection{Compressor}

Calibration testing of the first REH-30 compressior was completed with good results. Measured adiabatic efficiency for this compressor is $83 \%$ as compared to the design objective of $76 \%$.

\subsection{REH-30 Packaging}

Upon completion of air flow testing at Lau Industries, the REH-30 outdoor unit was 


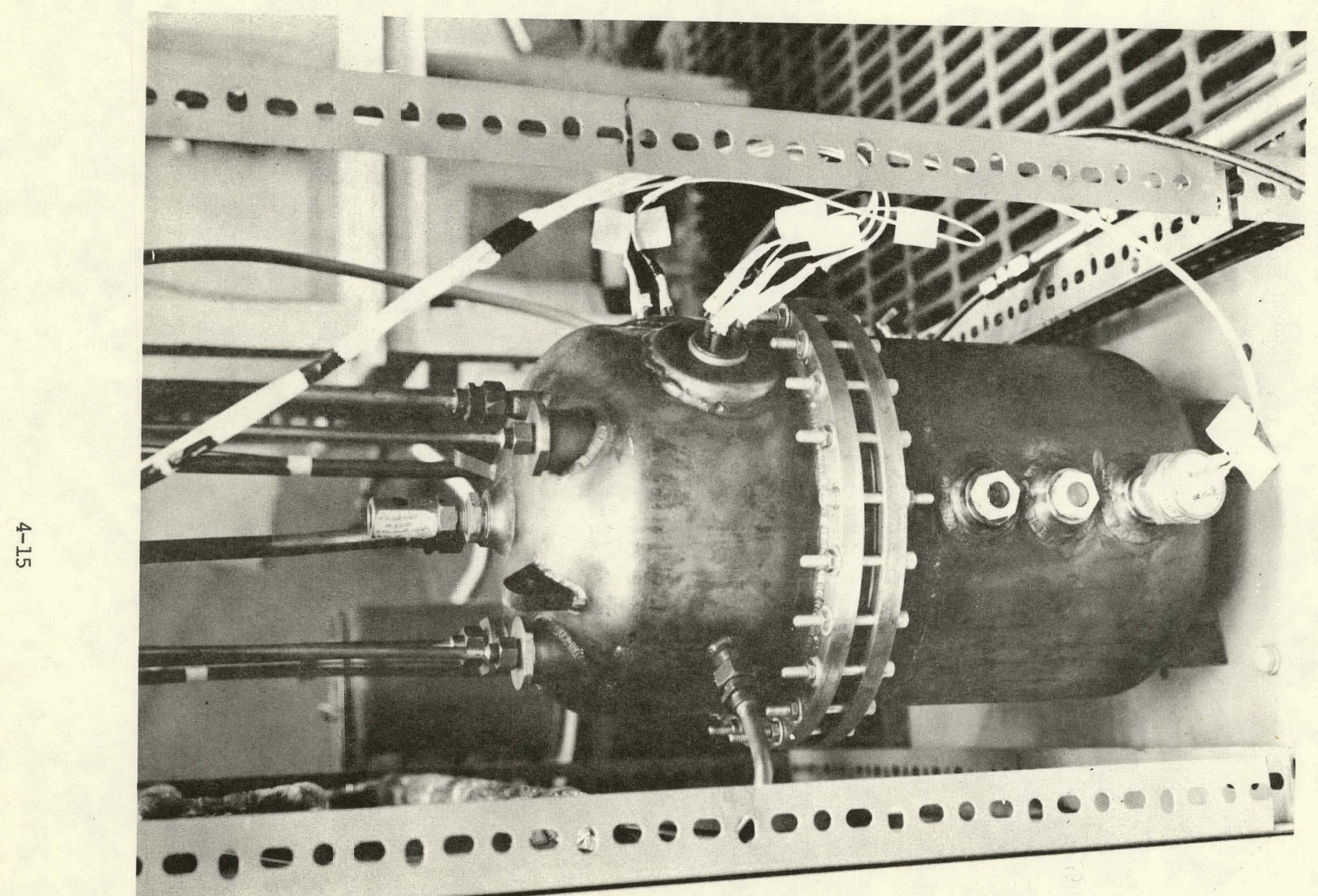

FIGURE 4-6. REH-30 FEED PUMP ON TEST 
shipped to GE-ACBD, Tyler, Texas where the compressor and other heat pump components were installed. Testing of the heat pump with the electric motor deive was conducted in both the heating and cooling mode. A $110^{\circ} \mathrm{F}$ condensing temperature for a $95^{\circ} \mathrm{F}$ day was achieved, and a cooling capacity of $37,100 \mathrm{Btu} / \mathrm{hr}$ was obtained with an EER rating of approximately 11 .

A more detail test report will be prepared including cooling and heating data.

The REH-30 indoor and outdoor units were received at GE-Space Divison, Valley Forge, $P A$ on $9 / 27 / 78$. During the next quarter, the Rallkine engine components will be installed to complete the REH-30 sub-assembly.

\subsection{Test}

\subsubsection{Low Temperature Rankine Component Test Loops}

The 3-ton "B" test loop facility is now fully operational. The facility is capable of testing the new two-stage expander using FC-88 as the working fluid and Krytox oil as the lubricant. Higher temperature water is available at the vapor generator, $320^{\circ} \mathrm{F}$ as compared to $295^{\circ} \mathrm{F}$ previously. Higher range temperature and pressure sensors were installed to be compatable with the new operating conditions. Figure 4-7 is a schematic representation of the expander test facility.

The design effort is well underway for upgrading to 10-ton expander test facility. Figures 4-8 thru 4-12 depict the components, interconnecting piping, valves, flow meters, torque meter and support stand for the 10-ton expander. The shaded areas presently exist and the unshaded area represent new piping, components, sensors etc. It is planned to complete the test facility modifications during the 4th Quarter 1978. 


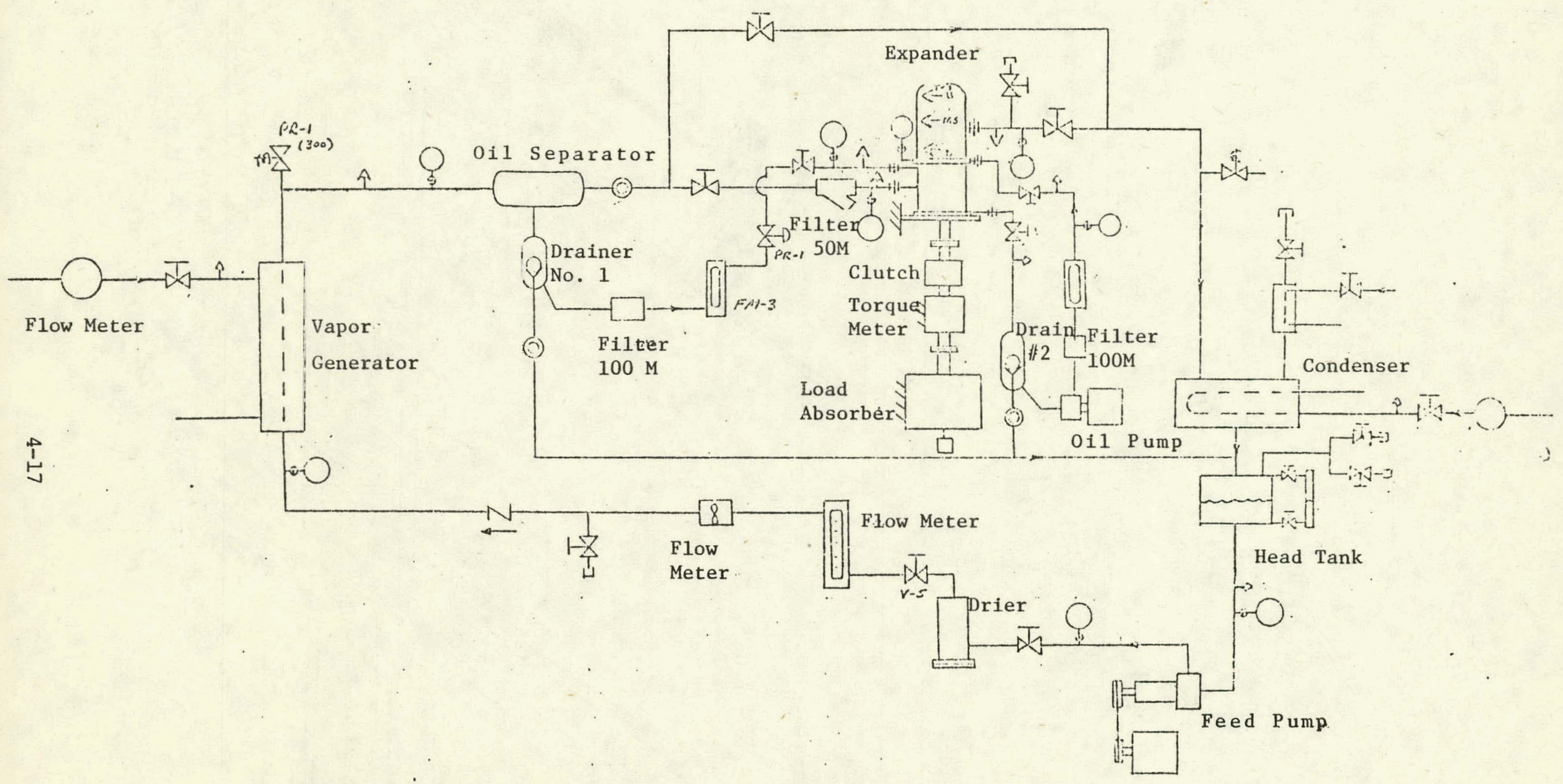

FIGURE 4-8. SCHEMATIC FOR TEST FACILITY FC-88, TWO STAGE EXPANDER 


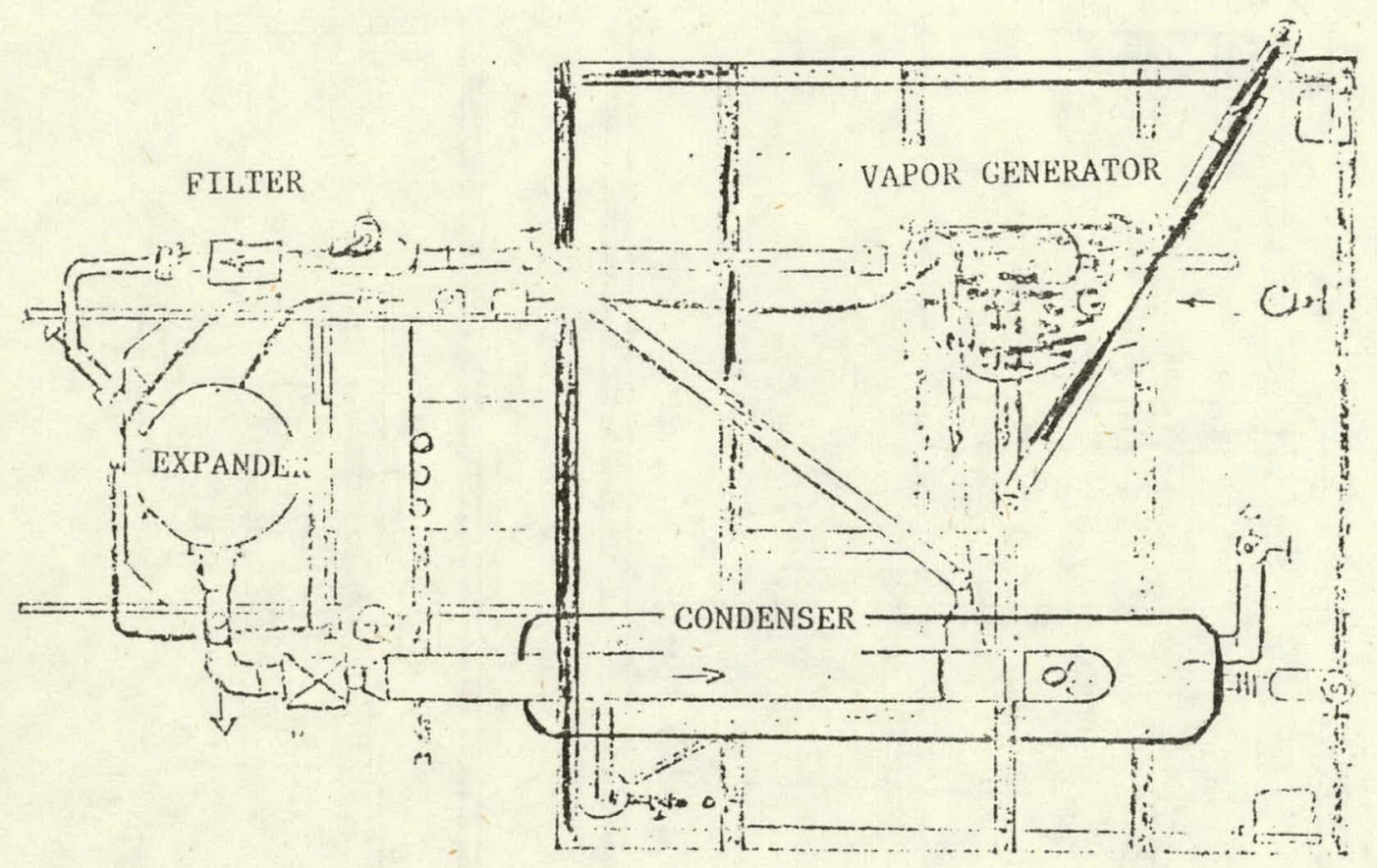

FIGURE 4-10. 10 TON EXPANDER FACILITY 


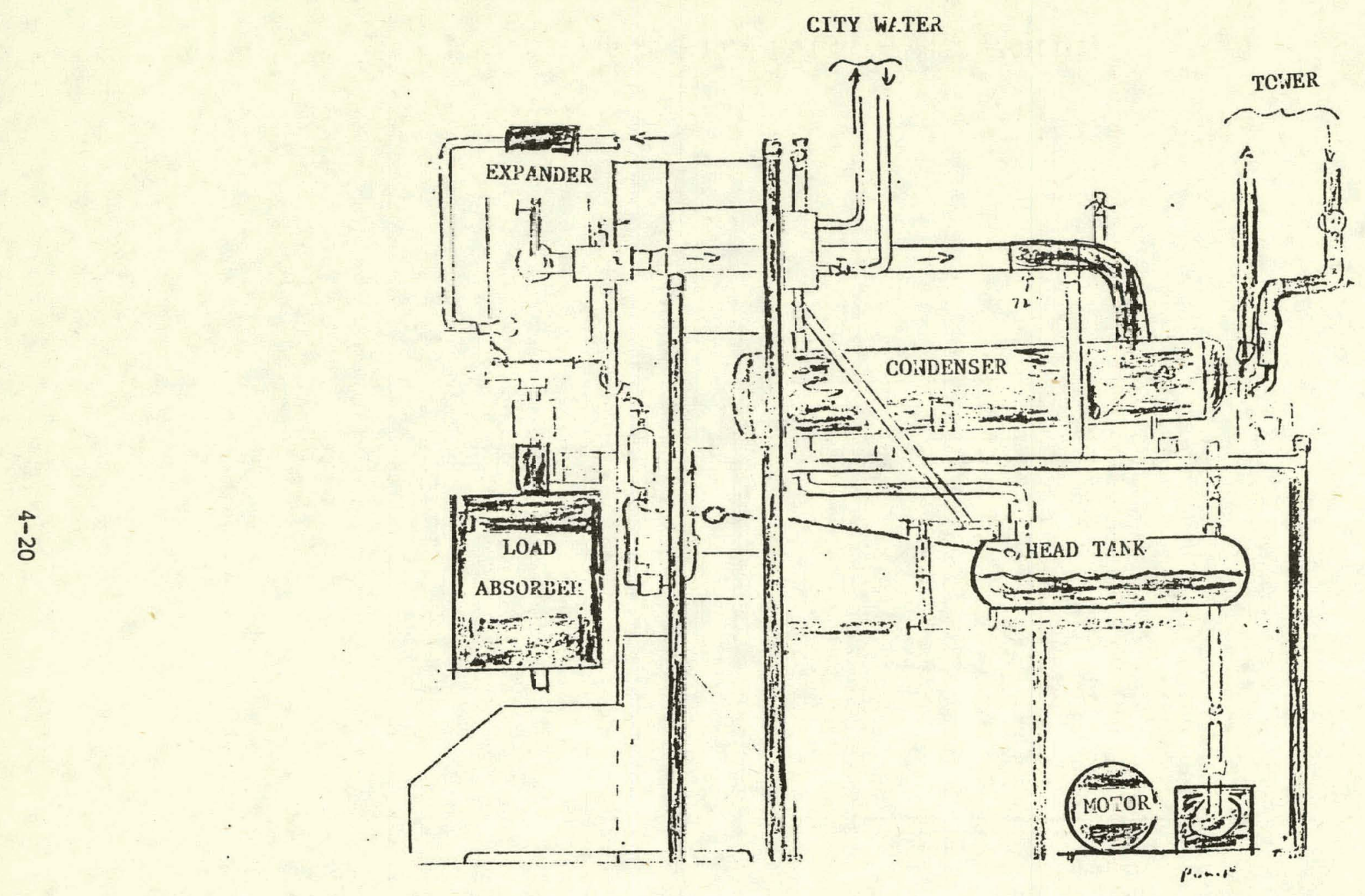

FIGURE 4-11. 10 TON EXPANDER FACILITY ELEVATION VIEW 


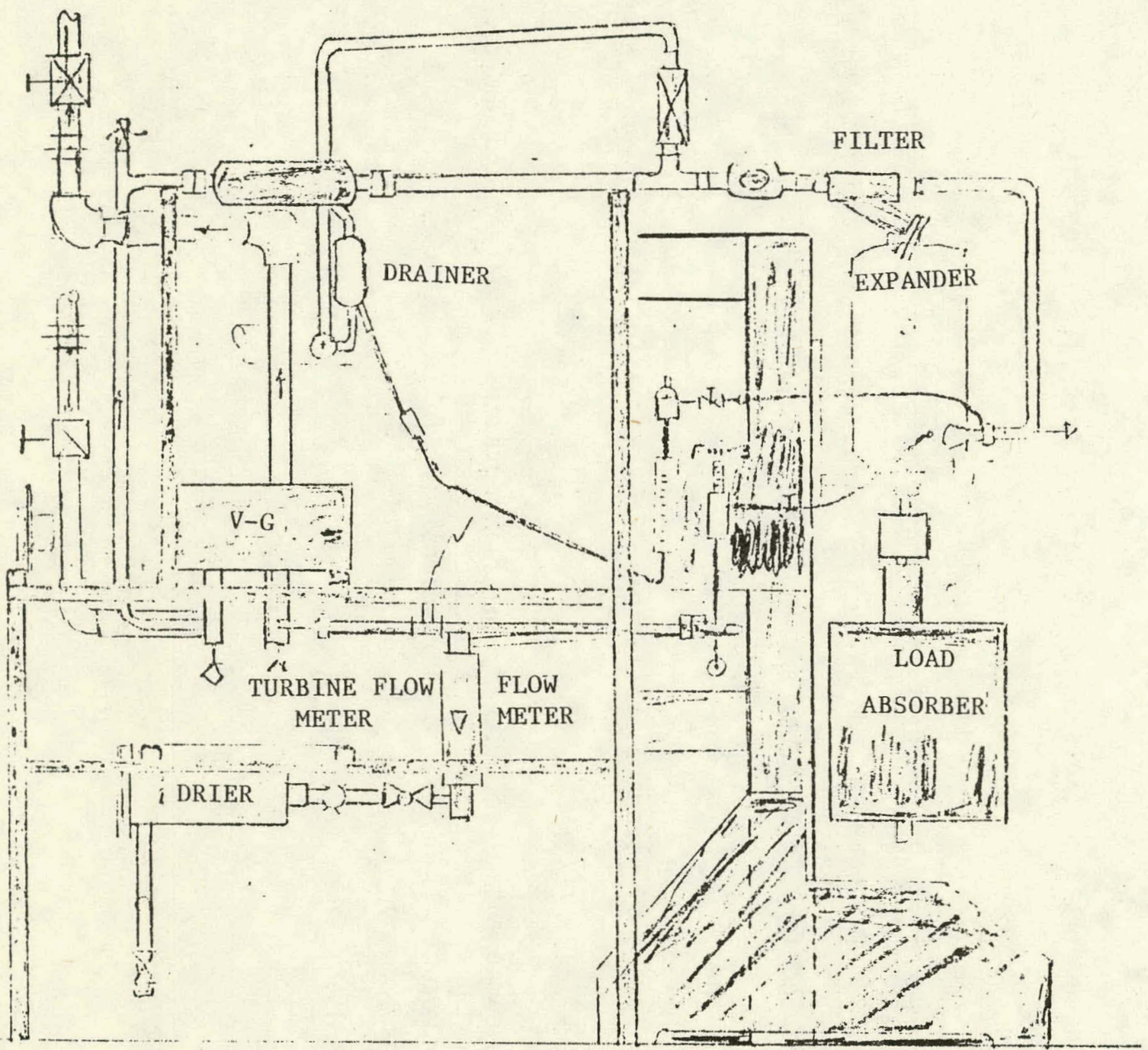




\section{SECTION 3}

TASK 1.3 - DELIVERABLE HARDWARE

\subsection{Norma1, 111.}

Delivery of all hardware completed.

\subsection{Spokane, Wash.}

Delivery of the modified controls hardware was the last item to be shipped.

\subsection{Milwaukee, Wisc.}

The initial shipment of collector frames and associated hardware is planned for October 27, 1978. The controls, V4 valve, V5 valve, control sensors and hydronic coil are scheduled for mid-Novmeber and the glass shrouds will follow.

\subsection{Ft. Meade, Md.}

The initial shipment of hardware, collectors, EMM, and associated hardware, were shipped September 25, 1978.

The remaining components, i.e., tanks, Solar Integrators, V4 valves and DHW coil will be shipped by October 19, 1978. Glass shrouds will follow on November 17, 1978 to complete the delivery. 


\section{SECTION 4}

\section{TASK 1.4 - OPERATIONAL TEST SITES}

\subsection{SITE IDENTIFICATION}

Two additional sites were identified for potential use, but neither has been visited to date. The first is a single-family residence in Shenandoah, Georgia being built under sponsorsinip of Georgia Power Co. The house as designed, will have too low of a load. Georgia Power has agreed to use standard construction techniques for one house to provide the required load. The second potential site is a TVA building in Murphy, North Carolina. The building is still in the conceptual design phase.

A summary of the site candidates that have been visited is shown in Table 4-3. The status of the operational test sites is given in Table 4-4.

\subsection{SITE INSTALLATIONS}

\subsubsection{Norma 1, 111, HSF-2 (OTS-32)}

The system was brought up to a operational status with a changeover of valve $V 4$ and replacement of the Solar Integrator with the permanent unit. The data system for the site malfunctioned over a portion of this period.

A test to evaluate potential elimination of the heat dump was scheduled for the end of July. Cloud cover obscured the sun after 10:00 A.M. on 8/1/78, and the test could not be concluded. The TES tank fluid was changed, and Puron 84 was added as the inhibitor. 
Table 4-3. Sites Inspected bेy GE

\begin{tabular}{|c|c|c|c|}
\hline Bldg. & Type & General City & Site \\
\hline HSF & & Baltimore & 7502 Young St., Ft. Meade, MD \\
\hline HCOM & & Muscle Shoals & TVA Office at Múscle Shoals, AL \\
\hline HMF & & Nashville & Airman's Quarters, AEDC, Tullahoma, TN \\
\hline HSF & & Peoria & Chanute Air Force Base \\
\hline HSF & & Peorla - & MA, Champaign, Illinois \\
\hline HSF & & Peoria & ISU House, Normal, Illinois \\
\hline HMF & & Schenectady & MHA, Schenectady, NY \\
\hline HMF & · & Schenectady & VA Hospital Staff Housing, Albany, $N Y$ \\
\hline IDAF & . & Schenectady & Ely Park Housing, Binghamfon, NY \\
\hline HCMF & & Chicágo & Ft. Sheridan, ILL \\
\hline HCMF & & Chicago & Great Lakes Naval Training Center \\
\hline HCOM & & Madison & Hill Farm State Office Bldg., Madison, WI \\
\hline HCOM & & Milwaukee & Washington Park Senior Citizens Center \\
\hline HCOM & & Mi lwaukee & Washington Park Community Center \\
\hline HCOM & & Milwaukee & Dr. Martin Luther King Community Center \\
\hline HCOM & & Spokane & YWCA \\
\hline $\mathrm{HCOM}$ & & Spokane & East Washington State College \\
\hline HCOM & & Spokane & Conmunity college \\
\hline HCCOM & & Los Angeles & West I.A. Municlpal Building \\
\hline HCCOM & & Los Angeles & Department of Water \& Power 非 1 \\
\hline HCCOM & - & Los Angeles & Department of Vater \& Power 非 2 \\
\hline HCCOM & & Los Angeles & Peck Park Recreation Building \\
\hline HCCOM & & Los Angeles & Police Credit Union \\
\hline HCSF & & Dallas & Pres1dent's Home, Univ: of Texas, Dallas \\
\hline HCSF & & Dallas & President's Home, N. Texas State, Denton, TX \\
\hline HCSF & & Dallas & Grad Student Housing at SNU \\
\hline HCSF & & Philadelphia & Visitor's Center, Valley Forge National Park \\
\hline HCSF & & Philadelphia & Rental House, Valley Forge National Park \\
\hline $\mathrm{HCSF}$ & & Philadelphia & Ampitheatre, Valley Forge National Park \\
\hline HCSF & & Philadelphia & Storage Barn, Valley Forge National Park \\
\hline
\end{tabular}


Table 4-4. Operational Test Site Status (9/30/78)

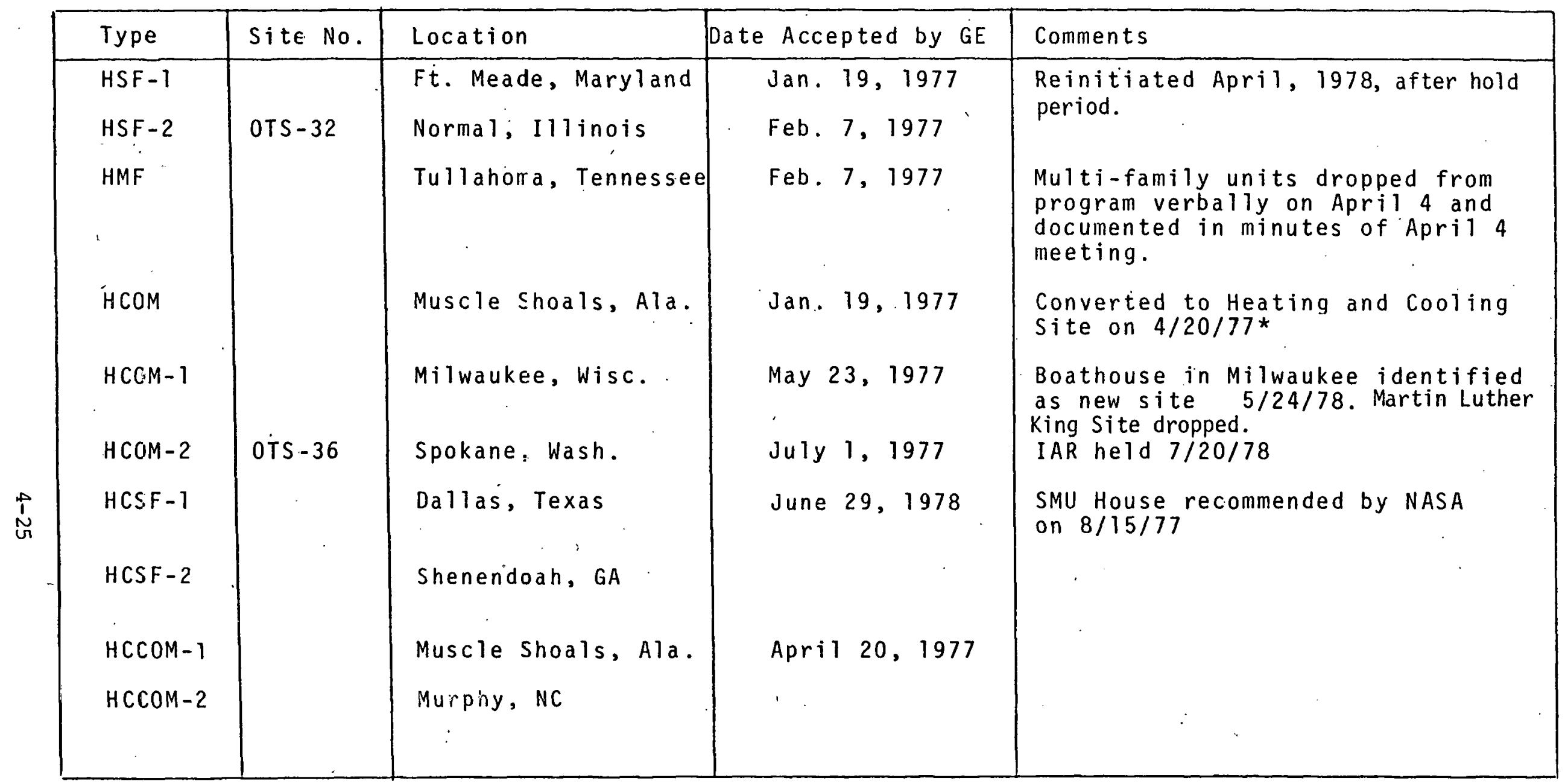

* Design activity was on hold pending this decision

Note: Great Lakes, Ill. was accepted as ä HCMF site on 2/7/77. All multi-family sites have been dropped from the program 
The system has been operating properly as of 8/7/78. after Pump P2 had regained operation since losing prime during TES fluid changeover on $8 / 1 / 78$. The pump was operating dry and primed itself on Sunday, 8/6/78. The system has been operating at a $35 \%$ to $45 \%$ efficiency level at temperatures above $200^{\circ} \mathrm{F}$. Some data taken in late August showed a reduction in collector loop flow rate over the noon period and restoration of full flow later in the afternoon. This phenomenon is systematic of local boiling in the system, but is not a concern of heating only systems. This condition will be addressed in the heating and cooling system design.

The Installation Acceptance Review was held on $9 / 7 / 78$. Action items resulting from that review were settled by the end of this period except for one replacement of the fluid actuated $V 4$ on the roof with a mechanically actuated unit. The basis for the change was that the hydraulic actuator has a low operating temperature limit of $0^{\circ} \mathrm{F}$ which is not adequate for Normal, I11. winters in a unconditioned unprotected environment.

\subsubsection{Spokane, Wash.}

The IAR was held on July 20, 1978 and the s.ystem is operating as designed. The man contamination problem was markedly reduced after removing valves $v 6$ and $V 7$. The recommended changes in the YWCA system were implemented and the problem disappeared completely.

There is a remaining concern with solar heating the swimming pool since 2 to 3 times as much energy is entering the pool than is coming from the solar system. An instrumentation check verified that the readings were correct. It is postulated that steam is leaking into the steam converter and adding the energy difference. Steps are being taken to verify that suspicion. The action items generated at the IAR and the last Quarterly Review have been settled. System efficiencies are similar to those demonstrated at Normal, I11. 


\subsubsection{Ft. Meade, Md.}

The Ft. Meade site is progressing. The majority of the solar equipment has been shipped and is in the hands of the contractor. The items missing are the new $V 4$ valve and the TES tank. A schedule is presented in Figure 4-13.

\subsubsection{Milwaukee, Wisc.}

The system design has been completed and the equipment has been ordered. The final design review has been held on $9 / 29 / 79$ and a bid package will be available in early October. A schedule for the installation is presented in Figure 4-14.

\subsubsection{Dallas, Tex.}

No significant activity occurred in this reporting period on GE's part. SMU has promised to provide an analysis of the the loss and gains, but these have not been received.

\subsubsection{Shenandoah, Geo.}

This site is on hold pending approval by NASA-MSFC.

\subsubsection{Muscle Shoals, Ala. and Murphy, N.C.}

Activity on these sites would be premature pending better definition of the 10-ton Rankine unit. There is no requirement at this time to accelerate the installation design. 


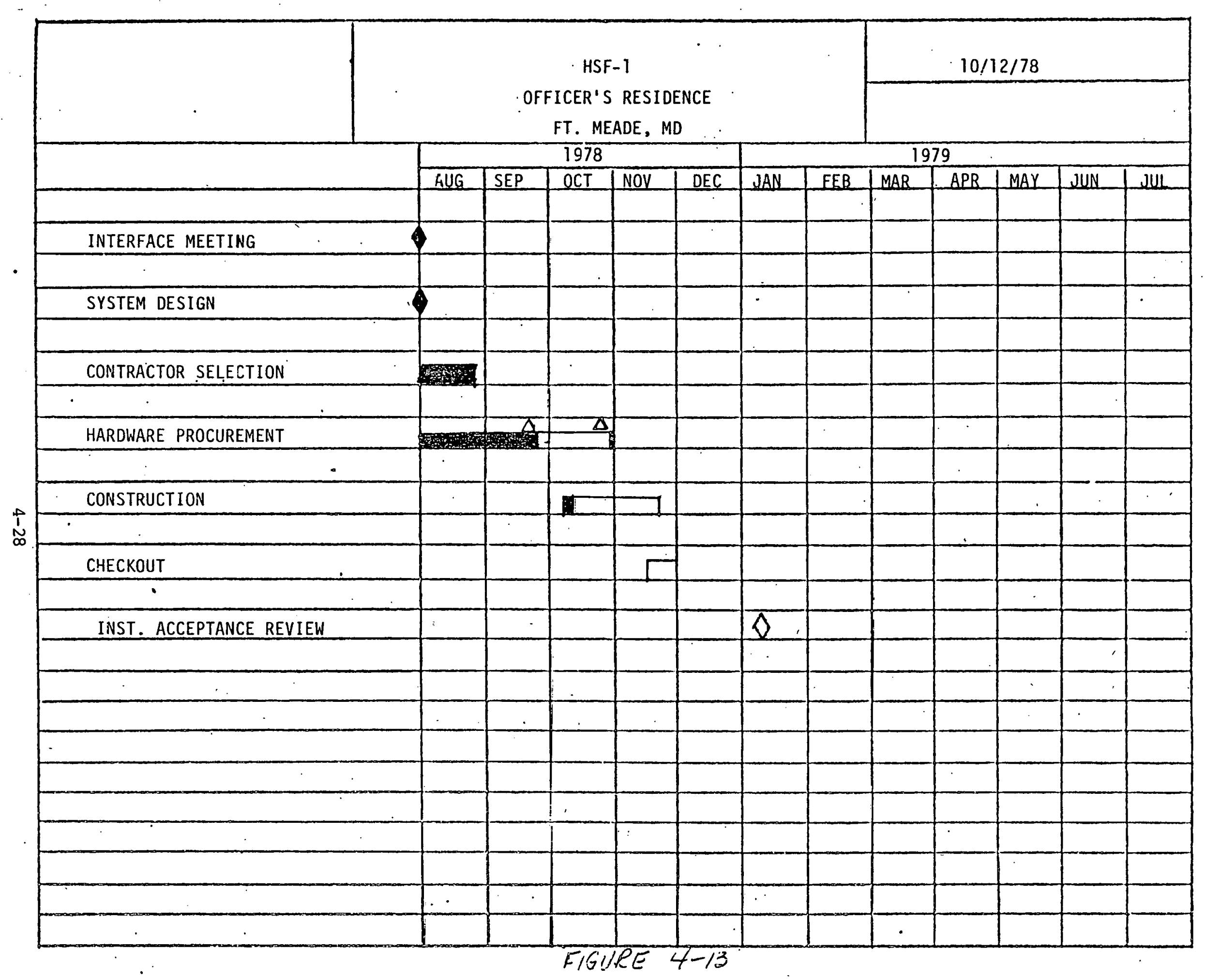


HCOM-1

$10 / 12 / 78$

WASHINGTON PARK COMMUNITY CENTER

MILHAUKEE, WI

.

INTERFACE MEETING

SYSTEM DESIGN

CONTRACTOR SELECTION

HARCWARE PROCUREMENT

i

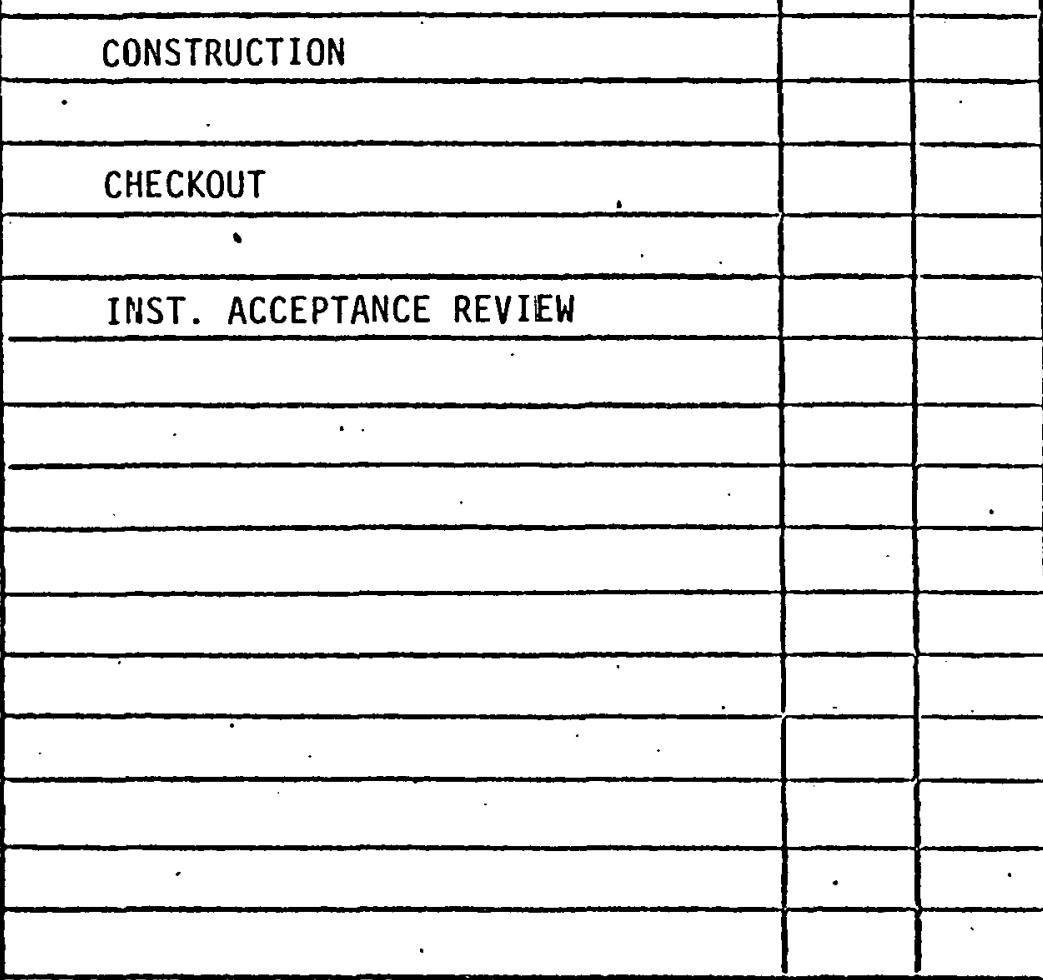

ZU.S. GOVERINMENT PRINTING OFFICE: $1980-640-247 / 311$ REGION NO. 4

\begin{tabular}{|l|l|l|l|l|l|l|l|l|l|l|l|l|}
\hline \multicolumn{3}{|c|}{1978} & \multicolumn{7}{|c|}{1979} \\
\hline AUG & SEP & OCT & NOV & DEC & JAN & FEB & MAR & APR & MAY & JUN & JUL \\
\hline
\end{tabular}

$+$
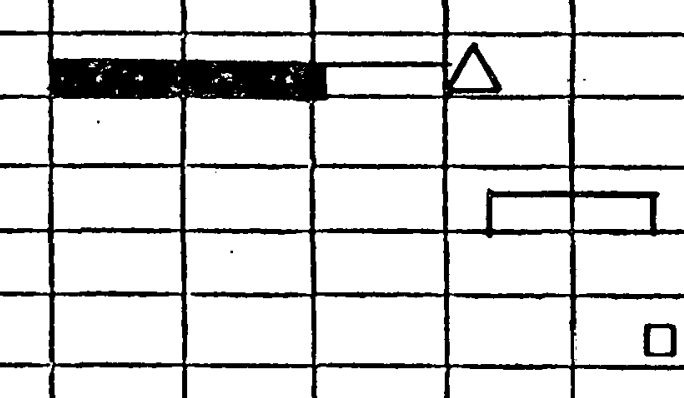

口

0 